\title{
Reduced 5-Lipoxygenase Metabolism of Arachidonic Acid in Macrophages rrom 1,25-dihydroxyvitamin $D_{3}$-Deficient Rats
}

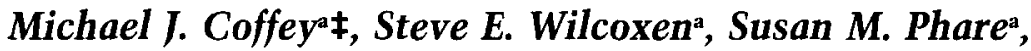 \\ Robert U. Simpson , Margaret R. Gyetko, \\ Marc Peters-Goldeñ $\mathbb{I}$
}

\begin{abstract}
aDivision of Pulmonary and Critical Care Medicine, Department of Internal Medicine, ${ }^{b}$ Department of Pharmacology, University of Michigan Medical School, Ann Arbor, Michigan 48109 and Medical Service, Veterans Affairs Medical Center, Ann Arbor, Michigan 48105
\end{abstract}

The peripheral blood monocyte (PBM) migrates into tissues and differentiates into mature tissue macrophages. Previous investigations from our laboratory have demonstrated that PBM have reduced 5-lipoxygenase (5-LO) metabolism of arachidonic acid (AA) and 5-LO activating protein (FLAP) expression as compared to differentiated alveolar macrophages (AM). Moreover, $P B M$ differentiated with 1,25-dihydroxyvitamin $D_{3}\left(1,25-(\mathrm{OH})_{2} D_{3}\right)$ displayed increased leukotriene synthesis and a parallel increase in FLAP expression. In the present study, we sought to examine the physiological role of 1,25$(\mathrm{OH})_{2} \mathrm{D}_{3}$ in the regulation of eicosanoid metabolism in terminally differentiated alveolar and peritoneal macrophages (PM), utilizing a well characterized rat model of vitamin $D_{3}$-deficiency. AM from vitamin $D_{3}$-deficient rats demonstrated reduced 5-LO metabolism of $A A$ and a parallel reduction in FLAP expression compared to control rats. Similarly, PM from vitamin $D_{3}$-deficient rats demonstrated reduced 5-LO metabolism of $A A$. The effect of vitamin $D_{3}$ was specific for the 5-LO pathway, not affecting total release of $A A$ or its metabolism via 12-lipoxygenase or cyclooxoygenase

Address correspondence to: Michael J. Coffey M.D., Division of Pulmonary and Critical Care Medicine, 3916 Taubman Center, 1500 E Medical Center Drive, Ann Arbor MI 48109-0360.

$\ddagger$ Recipient of a Clinical Investigator Development Award from the National Heart, Lung, and Blood Institute.

Il Recipient of a Career Investigator Award from the American Lung Association. 
Eicosanoid metabolism in vitamin $D_{3}$-deficient rats: Coffey et al.

(COX) pathways in macrophages. Furthermore, it did not affect COX protein expression in macrophages or type II alveolar epithelial cells. In control animals, 1,25- $(\mathrm{OH})_{2} D_{3}$ concentrations were greater in bronchoalveolar lavage fluid (2.6-fold) and peritoneal lavage fluid (1.6-fold) than in serum, which may account for the greater FLAP expression in AM and PM than in PBM. These observations suggest that $1,25-(\mathrm{OH})_{2} D_{3}$ plays a physiological role in upregulating the 5LO pathway in tissue macrophages in vivo.

Keywords: Eicosanoids; leukotrienes; prostaglandins; vitamin $\mathrm{D}_{3}$; alveolar; peritoneal

\section{Introduction}

Macrophages provide first line protection against exogenous toxins and invading microorganisms. All tissue macrophages arise by emigration from the bloodstream and subsequent differentiation of a bone marrowderived precursor, the peripheral blood monocyte (PBM). Differentiation of various cell types is promoted by 1,25 -dihydroxyvitamin $D_{3}(1,25$ $\left.(\mathrm{OH})_{2} \mathrm{D}_{3}\right)^{4,21}$ In particular, $1,25-(\mathrm{OH})_{2} \mathrm{D}_{3}$ has been shown to differentiate PBM to a more mature macrophage phenotype, as judged by the expression of maturation-associated antigens, and release of tumor necrosis factor and interleukin-6. ${ }^{16}$

The ability of macrophages to play an important role in host defense mechanisms is related, in part, to their capacity to generate various mediators, which include eicosanoids. Leukotrienes (LTs) are potent mediators of inflammation derived from the 5-lipoxygenase (5-LO) pathway of arachidonic acid (AA) metabolism which have been implicated in a wide range of immune and inflammatory diseases, including asthma, rheumatoid arthritis, inflammatory bowel disease and psoriasis. ${ }^{10,18}$ In most resting cells, the enzyme 5-LO resides predominantly in the soluble subcellular fraction. ${ }^{15,27}$ Upon cell activation, 5-LO interacts with 5-LO activating protein (FLAP), a particulate protein ${ }^{22}$ which has been shown to be necessary for LT synthesis. ${ }^{8}$ Ordinarily, PBM metabolize AA to only small amounts of LTs, favoring metabolism via the prostaglandin $\mathrm{H}$ synthase or cyclooxygenase (COX) pathway to prostaglandins (PGs) instead. ${ }^{1}$ We have recently shown that this lesser ability to synthesize LTs is due primarily to their reduced expression of FLAP compared to AM. ${ }^{7}$ Interestingly, incubation of PBM with the differentiating agent 1,25$(\mathrm{OH})_{2} \mathrm{D}_{3}$ resulted in parallel increases in 5-LO metabolism of endogenous AA as well as in FLAP expression. ${ }^{5}$

In view of the capacity of $1,25-(\mathrm{OH})_{2} \mathrm{D}_{3}$ to upregulate LT synthesis in vitro, we wished to determine whether $1,25-(\mathrm{OH})_{2} \mathrm{D}_{3}$ plays a physiological role in the regulation of the 5-LO pathway in macrophages in vivo. This 
question was addressed by utilizing a well-characterized rat model of vitamin $\mathrm{D}_{3}$-deficiency. We hypothesized that macrophages from vitamin $\mathrm{D}_{3}$-deficient rats (D-) would demonstrate reduced 5-LO metabolism of AA and FLAP expression as compared to normal rats $(\mathrm{D}+1$. Both 5-LO and COX pathways, along with the expression of 5-LO, FLAP and COX proteins, were therefore compared in two terminally differentiated macrophage populations, AM and peritoneal macrophages (PM). For purposes of comparison, a non-macrophage cell, the type II alveolar epithelial cell (AEC) which lines the pulmonary alveolar space, was studied. This cell metabolizes AA largely via the COX pathway lacking appreciable levels of 5-LO or FLAP proteins.

\section{Materials and Methods}

$D-$ and $D+$ rats

Animal studies were performed after approval from the Unit for Laboratory Animal Medicine at the University of Michigan. Sprague-Dawley rats specially bred from D - mothers (Harlan, Madison, WI) were housed in pathogen-free conditions under non-fluorescent lighting. The rats were rendered $\mathrm{D}$ - by feeding for 9 weeks with a vitamin $\mathrm{D}_{3}$-free diet which was supplemented with $2.5 \% \mathrm{Ca}^{2+}$ and $1.5 \% \mathrm{PO}_{4}$ (Teklad, Madison, WI, lot \# 86029) to maintain serum $\mathrm{Ca}^{2+}$ levels within normal limits, as described. ${ }^{32} \mathrm{D}+$ rats were obtained from the same source and housed under identical conditions, but the above diet was supplemented daily with $2 \mathrm{IU}$ vitamin $\mathrm{D}_{3}{ }^{32} \mathrm{~A}$ separate group of normal pathogen-free SpragueDawley rats was used to determine the $1,25-(\mathrm{OH})_{2} \mathrm{D}_{3}$ levels in alveolar and peritoneal lining fluid. These animals were of the same strain, sex, size, and housed under identical pathogen-free conditions as the $\mathrm{D}+$ and $\mathrm{D}$ - animals.

\section{Isolation and Culture of AM and PM}

Paired animals from $\mathrm{D}-$ and $\mathrm{D}+$ groups were studied in parallel. Rat $\mathrm{AM}$ and PM were harvested by bronchoalveolar lavage (BAL) and peritoneal lavage, respectively, as described. ${ }^{6}$ Lavage buffer consisted of 150 $\mathrm{mM} \mathrm{NaCl}, 2.7 \mathrm{mM}$ EDTA, $20 \mathrm{mM}$ HEPES, $5.5 \mathrm{mM}$ dextrose, 100 units/ $\mathrm{ml}$ penicillin, $100 \mu \mathrm{g} / \mathrm{ml}$ streptomycin, and $0.25 \mathrm{mg} / \mathrm{ml}$ amphotericin B. Lavaged cells (BAL $>94 \%$ and peritoneal lavage $>81 \%$ macrophages) were either studied fresh or were adhered $(>98 \%$ macrophages) and cultured in medium 199 (M199) as described. ${ }^{26}$

\section{Isolation and Culture of Rat Type II AEC}

Type II AEC were isolated by a standard technique. ${ }^{9}$ Cells were suspended in Dulbecco's modified Eagle's medium (DMEM; GIBCO, Grand Island, 
Eicosanoid metabolism in vitamin $D_{3}$-deficient rats: Coffey et al.

$\mathrm{NY}$ ) containing $10 \%$ fetal calf serum (FCS) with 100 units $/ \mathrm{ml}$ penicillin, $100 \mu \mathrm{g} / \mathrm{ml}$ streptomycin, and $0.25 \mathrm{mg} / \mathrm{ml}$ amphotericin $\mathrm{B}$ at $1.5 \times 10^{6}$ cells $/ \mathrm{ml}$ and $2 \mathrm{mls}$ of cell suspension added to $35 \mathrm{~mm}$ culture dishes (Falcon). Cells were cultured in a humidified atmosphere of $5 \% \mathrm{CO}_{2}$ in air at $37^{\circ} \mathrm{C}$. The day of isolation and plating was designated culture day 0 . By day 2 , cells form a confluent monolayer of which $\sim 94 \%$ are epithelial cells as judged by cytokeratin staining. ${ }^{19}$

\section{$1,25-(\mathrm{OH})_{2} D_{3}$ Assay}

Serum and lavage fluid samples were assayed for $1,25-(\mathrm{OH})_{2} \mathrm{D}_{3}$ using the $1,25-(\mathrm{OH})_{2} \mathrm{D}{ }^{3} \mathrm{H}$ Radio Receptor Assay Kit (INCSTAR Corporation, Stillwater, $\mathrm{MN}$ ) as described. ${ }^{13}$ Briefly, the assay involves a preliminary extraction and subsequent purification of vitamin $\mathrm{D}$ metabolites from serum or fluid using a $\mathrm{C}_{18}$ cartridge. Quantitation is achieved via a non-equilibrium competitive protein binding assay using a $1,25-(\mathrm{OH})_{2} \mathrm{D}{ }^{3} \mathrm{H}$ tracer and a thymus receptor that is specific for $1,25-(\mathrm{OH})_{2} \mathrm{D}$. Dextran-coated charcoal is then incubated with the sample-receptor cocktail, binds to the unbound hormone, and is pelleted by centrifugation. The supernatant, which contains the thymus receptor-bound hormone, is decanted into a scintillation vial and counted. Values are corrected for extraction efficiency using a recovery factor and final concentration of $1,25-(\mathrm{OH})_{2} \mathrm{D}_{3}$ in the sample is expressed as $\mathrm{pg} / \mathrm{ml}$.

\section{Analysis of AA metabolism in Intact Cells}

Cell lipids were prelabeled by incubation with $1 \mu \mathrm{Ci}\left[{ }^{3} \mathrm{H}\right] \mathrm{AA}$ (sp. act 60-100 Ci/mmol; Dupont-New England Nuclear, Boston MA) in M199 containing 10\% FCS during overnight culture. Cells were washed and the maximal capacity for eicosanoid synthesis was determined by incubation in M199 for 30 min with ionophore A23187 (Calbiochem, La Jolla, $\mathrm{CA}$ ), diluted to a final concentration of $1 \mu \mathrm{M}$ in DMSO (final concentration $0.5 \%$ ). Medium from cultures was extracted using $C_{18}$ Sep-Paks (Waters, Milford, CA), and eicosanoids were separated by reverse-phase HPLC, identified by co-elution with authentic stanc ards, and quantitated by scintillation counting of fractions. ${ }^{1}$ In selected experiments 5 -LO metabolic capacity of unlabeled A23187-stimulated cells was estimated by enzyme immunoassay (EIA) (Cayman, Ann Arbor, MI) of the cellular supernatants for $\mathrm{LTB}_{4}$, the major 5-LO product of rat AM and PM. ${ }^{26}$.

\section{Cell Lysis and Subcellular Fractionation}

Fresh or cultured cells were suspended in homogenization buffer $150 \mathrm{mM}$ potassium phosphate, $100 \mathrm{mM} \mathrm{NaCl}, 2 \mathrm{mM}$ EDTA, $1 \mathrm{mM}$ dithiothreitol, $0.5 \mathrm{mM}$ PMSF, and $60 \mu \mathrm{g} / \mathrm{ml}$ soybean trypsin inhibitor, $\mathrm{pH}$ 7.1). They 
Eicosanoid metabolism in vitamin $D_{3}$-deficient rats: Coffey et al.

were disrupted by sonication on iced ethanol using a model 250 Sonifier (Branson Ultrasonics Corp., Danbury, CT) at power level 1 and 20\% duty cycle for $1.5 \mathrm{~min}$, achieving $>98 \%$ lysis. Lysates then underwent centrifugation at $100,000 \times \mathrm{g}$ for $60 \mathrm{~min}$ to obtain "soluble" (supernatant) and "particulate" (pellet) fractions. The particulate fraction was then rinsed twicc and resuspended in homogenization buffer by sonication (power level $1,100 \%$ duty cycle, $10 \mathrm{~s}$ ). Total protein content of subcellular fractions was determined using a microtiter plate modification of the Bradford method (Pierce, Rockford IL) with BSA as standard.

\section{Immunoblot Analysis of Total Cellular 5-LO, FLAP, and COX Proteins}

Steady-state protein levels of 5-LO, FLAP, and the two isoforms of COX, COX-1 and COX-2, were determined by immunoblot analysis using a modification of methods described previously. ${ }^{6}$ Briefly, equal amounts of protein $(5-20 \mu \mathrm{g})$ were separated by SDS-PAGE on $10 \%$ (5-LO, COX-1 and COX-2) and $15 \%$ (FLAP) gels, by the method of Laemmli. ${ }^{17}$ High and low molecular weight rainbow markers (Amersham, Arlington, IL) were also loaded on each gel. After overnight transfer to nitrocellulose membranes (Bio-rad Laboratories, Richmond, CA), blots were blocked by incubating for $1 \mathrm{~h}$ with $10 \%$ non-fat dried milk in Tris buffered saline (TBS), washed in TBS containing $0.1 \%$ Tween 20 (TBS-T), and incubated at room temperature for $1 \mathrm{~h}$ with rabbit polyclonal primary antibodies raised against the following: human leukocyte 5-LO (1:3000 dilution); amino acid residues 41-52 of the human FLAP sequence (1:5000 dilution) (both kindly provided by Dr. J. Evans, Merck Frosst, Dorval, Canada); sheep seminal vesicle COX-1 (1:5000 dilution) (both kindly provided by Dr. W. Smith, Michigan State University, E. Lansing, MI), and a 17-amino acid peptide derived from the murine COX-2 sequence not present in COXl (1:300 dilution) (kindly provided by Dr. D. DeWitt, Michigan State University). After washing, blots were incubated for $1 \mathrm{~h}$ with horseradish peroxidase-conjugated goat anti-rabbit IgG (Amersham) at a dilution of 1:5000 (5-LO, FLAP and COX-2), or 1:10,000 (COX-1) in TBS-T. Membranes were then washed and developed using the ECL chemiluminescent western blotting system (Amersham). Luminescent bands were quantitated by video densitometry using software from Scion Corp (Frederick, $\mathrm{MD})$.

\section{Data Analysis}

Where indicated, data were expressed as the mean \pm SEM. Statistical analysis was performed using a Student's $t$ test. A p value $<0.05$ was considered significant. 
Eicosanoid metabolism in vitamin $D_{3}$-deficient rats: Coffey et al.

\section{Results}

Body Weight, Cell Count, and 1,25-(OH $)_{2} D_{3}$ Levels

Pairs of $\mathrm{D}+$ and $\mathrm{D}$ - rats were sacrificed at 9 to 12 weeks and studied in parallel. Body weight of $\mathrm{D}-$ rats $(398.8 \pm 74.5 \mathrm{~g})$ was significantly less than that of $\mathrm{D}+$ rats $(501.2 \pm 79.7 \mathrm{~g})(\mathrm{p}<0.05, \mathrm{n}=9$ pairs $)$, but they exhibited no mortality or apparent morbidity. There were no differences in the numbers of macrophages obtained by lavage from $\mathrm{D}+(\mathrm{AM}, 13.7$ $\pm 9.2 \times 10^{6}$ per animal; PM, $\left.27.3 \pm 10.7 \times 10^{6}\right)$ and $\mathrm{D}-$ rats $(\mathrm{AM}, 15.8$ $\left.\pm 10.5 \times 10^{6} ; \mathrm{PM}, 17.7 \pm 6.7 \times 10^{6}\right)(\mathrm{p}=\mathrm{s}, \mathrm{n}=9$ pairs $)$. As expected, ${ }^{32}$ $1,25-(\mathrm{OH})_{2} \mathrm{D}_{3}$ levels in serum from $\mathrm{D}-$ rats $\left(1.8 \mathrm{pg} / \mathrm{ml}\right.$ or $0.5 \times 10^{4} \mathrm{pg} /$ $\mu \mathrm{g}$ of protein) were markedly less than from $\mathrm{D}+$ rats $(33.9 \mathrm{pg} / \mathrm{ml}$ or 9 $\times 10^{4} \mathrm{pg} / \mu \mathrm{g}$ of protein). $1,25-(\mathrm{OH})_{2} \mathrm{D}_{3}$ levels in BAL and peritoneal lavage fluids were measured from pooled samples obtained from a separate group of 4 normal control Sprague-Dawley rats, and in vivo vitamin $\mathrm{D}_{3}$ concentrations calculated by correcting for estimated volumes of alveolar lining fluid ${ }^{30}$ and peritoneal lining fluid. ${ }^{3}$ The calculated $1,25-(\mathrm{OH})_{2} \mathrm{D}_{3}$ concentrations in BAL fluid in normal control rats was $88 \mathrm{pg} / \mathrm{ml}$ (2.6-fold that of serum) and peritoneal lavage fluid was $56 \mathrm{pg} / \mathrm{ml}$ (1.6-fold that of serum).

Reduced 5-LO Metabolism of AA in AM and PM from Vitamin $D_{3}$ Deficient Rats

Having previously shown that in vitro exposure of PBM to the differentiating agent $1,25-(\mathrm{OH})_{2} \mathrm{D}_{3}$ upregulated LT synthetic capacity and FLAP expression, ${ }^{5}$ we were interested in determining whether $1,25-(\mathrm{OH})_{2} \mathrm{D}_{3}$ might have a physiological role in regulating these processes during macrophage differentiation in vivo. This was addressed by studying mature resident $\mathrm{AM}$ and PM obtained from $\mathrm{D}+$ and $\mathrm{D}-$ rats. Following A23187 stimulation, D+ AM elaborated free AA, 12-(S)-hydroxy-6,8,11,14-eicosatetraenoic acid (12-HETE), and the 5-LO products $\mathrm{LTB}_{4}$ and 5-(S)-hydroxy6,8,11,14-eicosatetraenoic acid (5-HETE), and small amounts of COX products $\left[\mathrm{PGE}_{2}\right.$, thromboxane [Tx] $\mathrm{B}_{2}$ and $\mathrm{HHT}$ [12-hydroxyheptadecatrienoic acid] were also seen, as expected ${ }^{26}$ (Figure 1A). Stimulated AM from D- animals released similar amounts of total radioactivity as did those from $\mathrm{D}+$ animals (data not shown). Amounts of 12-HETE and of COX products were also similar in cells from D - animals, but they released $65 \%$ less $\mathrm{LTB}_{4}$ and $67 \%$ less 5 -HETE than did AM from D+ animals (Figure 1A). An increase in unmetabolized AA in AM from D- animals $(82 \%$ of total radiolabel) as compared to $\mathrm{D}+\mathrm{AM}(68 \%)$ suggests a reduced ability to metabolize the available endogenous AA. The reduction in 5-LO metabolism of AA in AM from $\mathrm{D}$ - animals was confirmed by immunoassay of $\mathrm{LTB}_{4}$ (Figure $\left.1 \mathrm{~B}\right)(\mathrm{n}=4$ pairs, $\mathrm{p}<0.05)$.

PM were examined in similar fashion. HPLC analysis of A23187. stimulated products elaborated by prelabeled PM from D + rats indicated 


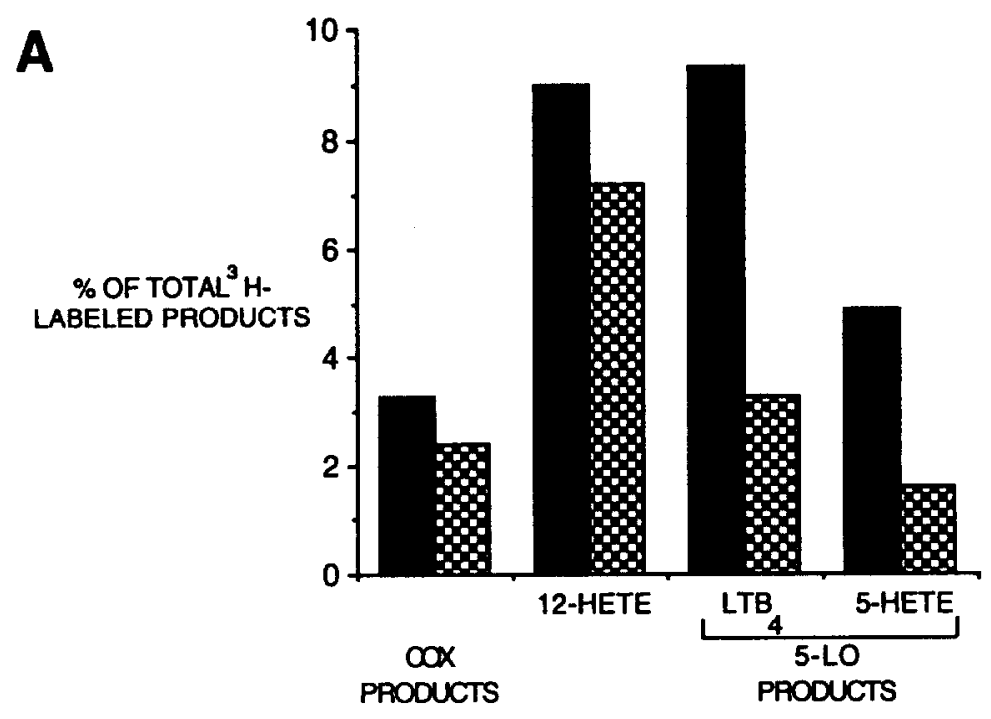

B
(\% OF D+ VALUE)

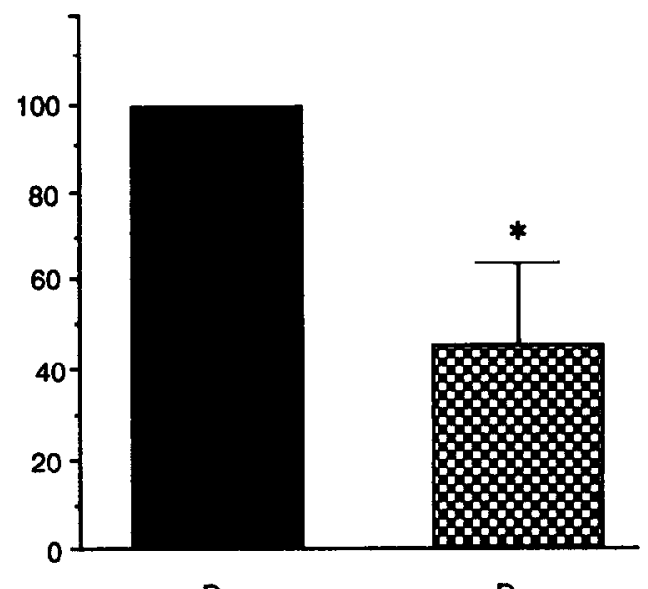

FigurE 1. Eicosanoid synthesis in $A M$ from $D+$ and $D-$ rats. (A) $A M$ from $D+$ and $D-$ rats were adhered for $1 \mathrm{~h}$ in M199 and lipids labeled during overnight incubation with [ $\left.{ }^{3} \mathrm{H}\right] \mathrm{AA}$. Cells were stimulated with $\mathrm{A} 23187(1 \mu \mathrm{M})$ for $30 \mathrm{~min}$ and radiolabeled eicosanoids separated by HPLC analysis, as described in the "Materials and Methods." For each metabolite or group of metabolites, data for $D+$ (solid bars) and D - (checked bars) are expressed as the percent of total "H-labeled products eluted. "COX products" include $\mathrm{TxB}_{2}, \mathrm{PGE}_{2}$, and HHT. "5-LO products" include $L_{T B}$ and 5-HETE. (B) Unlabeled AM from $D+$ and $D-$ rats were adhered for $1 \mathrm{~h}$ in M199, washed and stimulated with A23187. Medium was then harvested for quantitation of immunoreactive $\mathrm{LTB}_{4}$. Data for cells from $\mathrm{D}-$ (checked bars) rats are expressed as a percentage of the paired $D+$ (solid bars) value $(28.13 \pm 12.29 \mathrm{ng} / \mathrm{ml})$ and represent the mean \pm S.E.M. from 4 pairs of rats; ${ }^{*} p<0.05$. 
Eicosanoid metabolism in vitamin $D_{3}$-deficient rats: Coffey et al.

a predominance of COX metabolites, including $\mathrm{PGE}_{2}, \mathrm{TxB}_{2}, 6$-keto $\mathrm{PGF}_{1 \mathrm{a}}$ and HHT, over 5-LO products 5-HETE and $\mathrm{LTB}_{4}$, as previously reported. ${ }^{26}$ Small amounts of 12-HETE were also synthesized. Stimulated PM from $\mathrm{D}$ - animals released similar amounts of total radioactivity as did those from $\mathrm{D}+$ animals (data not shown). PM from $\mathrm{D}-$ animals generated similar quantities of COX and 12 -LO products, but $35 \%$ less 5 -LO products, than did PM from D + rats (Figure 2A). Likewise, the reduction in 5-LO metabolic capacity of AA in PM from D - animals was confirmed by EIA of $\mathrm{LTB}_{4}$ (Figure 2B) (n=4 pairs, $\left.\mathrm{p}<0.05\right)$.

\section{Reduced FLAP Expression in AM from Vitamin $D_{3}$ deficient Rats}

AM from D + and D - rats were compared for 5-LO and FLAP expression. Figure 3 presents representative autoradiographs, as well as mean densitometric analysis of such data from 4 pairs of rats. Lysates of fresh AM from both groups of rats contained 5-LO protein in both soluble and particulate fractions, as we have reported previously for normal resting rat AM. ${ }^{6}$ There was no difference in the subcellular distribution of 5-LO between $\mathrm{D}+$ and $\mathrm{D}-\mathrm{AM}$. Both subcellular fractions were thus analyzed by densitometry and combined to give the mean quantitative data. There was no difference in 5-LO expression in AM from $\mathrm{D}+$ and $\mathrm{D}-$ rats (Figure 3A). FLAP, by contrast, was only detected in the particulate fraction. Notably, cells from $\mathrm{D}-$ rats exhibited a $52 \pm 14.6 \%$ reduction in FLAP protein compared to D+AM (Fig. 3B) $(\mathrm{p}<0.05)$

In selected experiments, $A M$ from $D$ - rats were incubated overnight with $50 \mathrm{nM}$ exogenous $1,25-(\mathrm{OH})_{2} \mathrm{D}_{3}$. The addition of exogenous 1,25 $(\mathrm{OH})_{2} \mathrm{D}_{3}$ restored $\mathrm{LTB}_{4}$ synthetic capacity towards the level observed in $\mathrm{D}+$ cells (Figure 4B), and caused a corresponding increase in FLAP expression (Figure 4A). These data strongly suggest that the defects in 5-LO metabolism of AA and FLAP expression in D- AM were indeed related to $1,25 \cdot(\mathrm{OH})_{2} \mathrm{D}_{3}$ deficiency.

Likewise, the expression of 5-LO and FLAP was determined in PM from $\mathrm{D}+$ and $\mathrm{D}-$ rats. As previously reported, ${ }^{6} \mathrm{D}+\mathrm{PM}$ demonstrated a trend towards lower levels of 5-LO protein expression than D $\mathrm{AM}$ (5LO expression in PM as a \% of AM: $62.2 \pm 44.6 \%, n=3, p=s)$. FLAP expression was also comparable in the two cell types (FLAP expression in $P M$ as a $\%$ of $D+A M: 156.8+86.2 \%, n=3, p=s$, as previously

demonstrated. ${ }^{5}$ There was no significant difference in the subcellular distribution of 5-LO in PM from D - rats compared to D + rats (data not shown). There was no reduction ( $71 \%$ of $\mathrm{D}+$ ) in 5 -LO expression in AM from $\mathrm{D}$ - rats (data not shown). Similarly, cells from $\mathrm{D}-$ rats exhibited no reduction $(97.1 \pm 14.2 \%$ of $\mathrm{D}+)$ in FLAP protein compared to $\mathrm{D}+$ PM. 


\section{A}

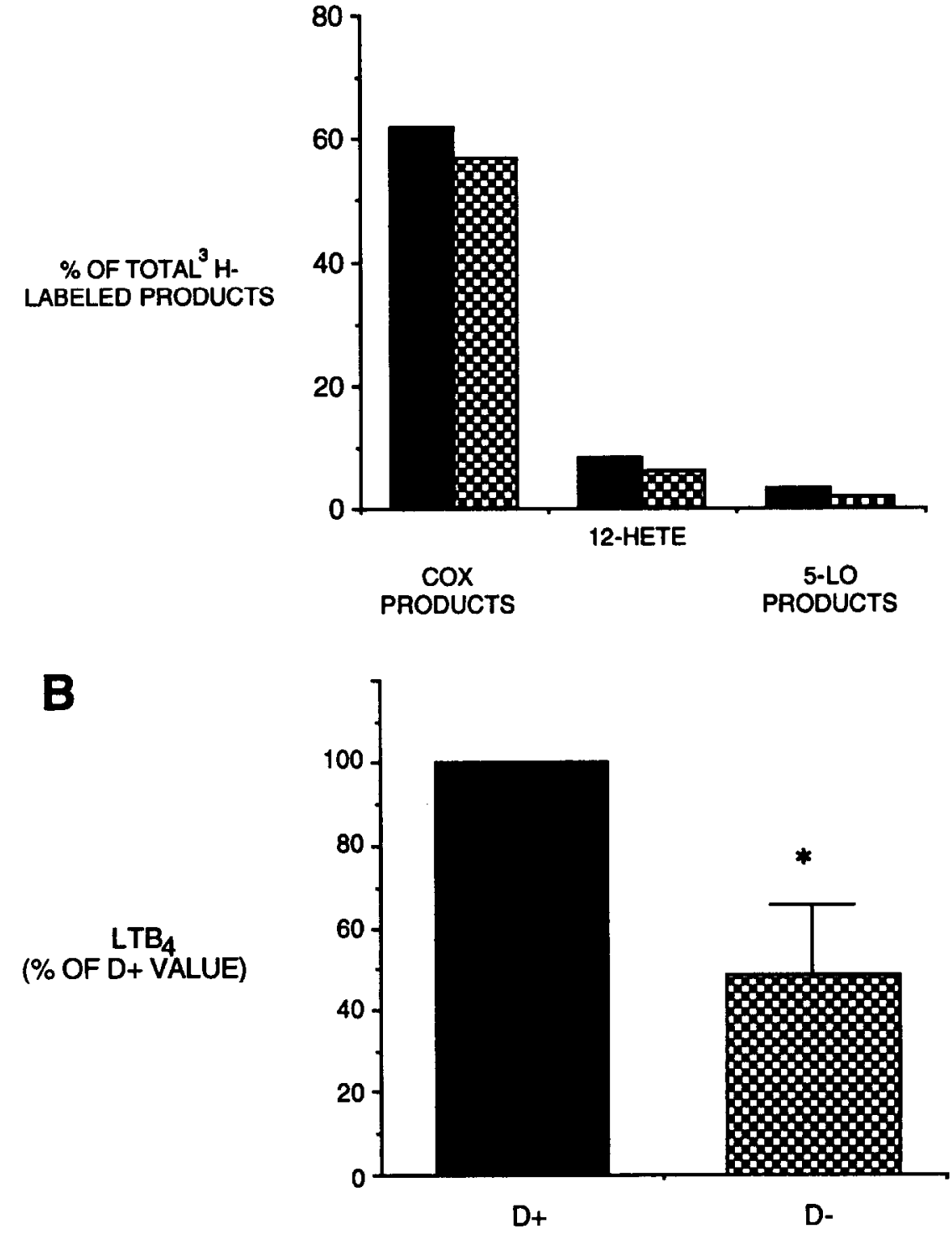

FiguRE 2. Eicosanoid synthesis in $P M$ from $D+$ and $D-$ rats. (A) $P M$ from $D+$ and $D-$ rats were adhered for $1 \mathrm{~h}$, labeled overnight with [ $\left.{ }^{3} \mathrm{H}\right] \mathrm{AA}$, and stimulated with A23187. Quantitation of individual metabolites or groups of metabolites for $D+$ (solid bars) and $D-$ (checked bars) are expressed as described in the legend to Figure 1. "COX products" include $\mathrm{TxB}_{2}, \mathrm{PGE}_{2}, 6$ keto PGF $_{1 \alpha}$ and HHT. "5-LO products" include LTB $_{4}$ and 5-HETE. (B) Unlabeled PM from D + and $D$ - rats were adhered, stimulated with $1 \mu \mathrm{M} \mathrm{A23187}$ for 30 min and the media harvested for quantitation of immunoreactive $\mathrm{LTB}_{4}$. Data for cells from $\mathrm{D}-$ rats are expressed as a percentage of the paired $D+$ value $(3.53 \pm 2.7 \mathrm{ng} / \mathrm{ml})$ and represent the mean \pm S.E.M. from 4 pairs of rats; ${ }^{*} p<0.05$. 

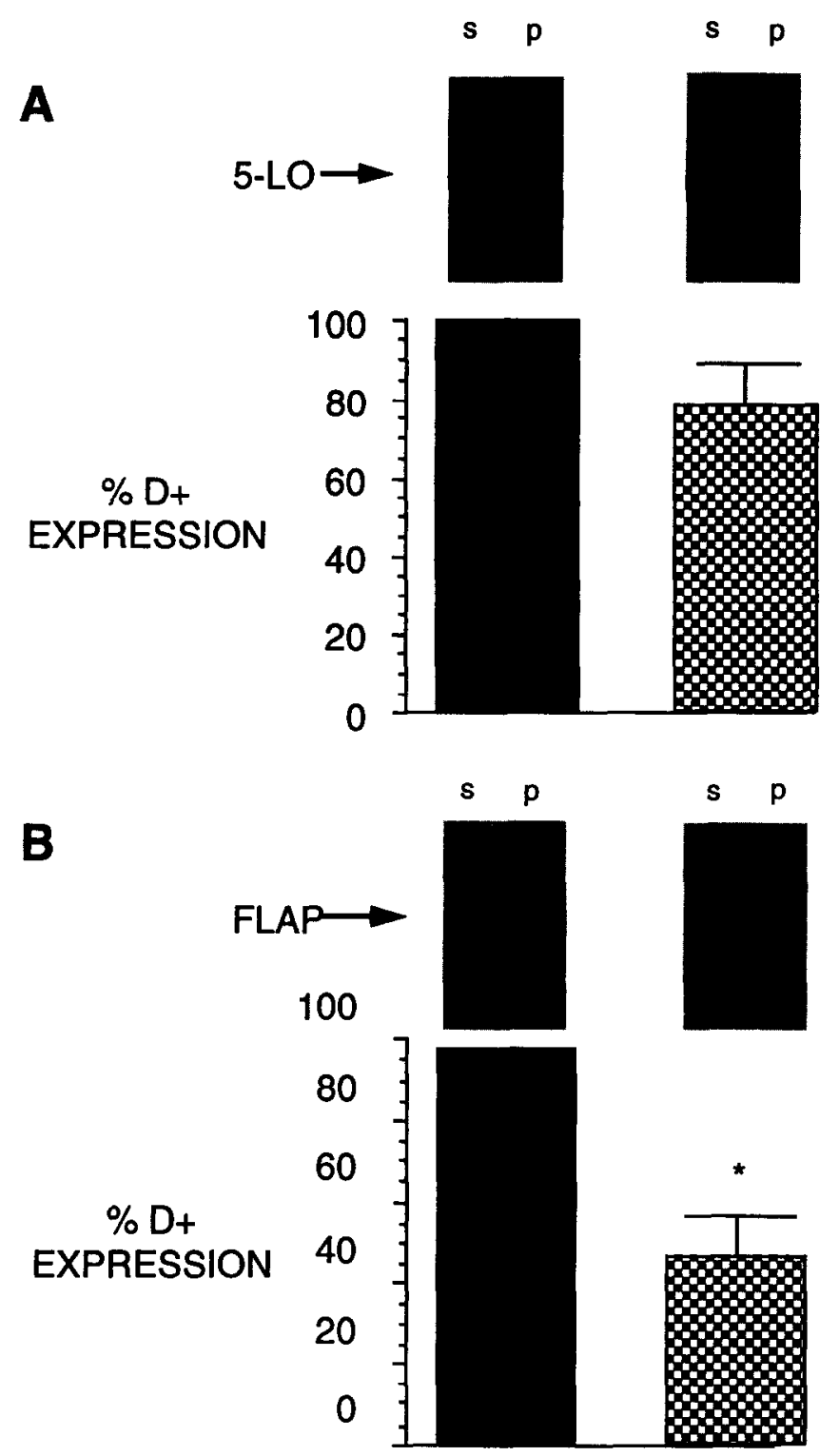

FIGURE 3. 5-LO and FLAP expression in AM from $D+$ and $D-$ rats. Equal amounts of soluble (s) and particulate $(p)$ proteins $(5-20 \mu \mathrm{g})$ obtained from $A M$ of $D+$ and $D$ - rats were subjected to immunoblot analysis of 5-LO (A) and FLAP (B) as described in the "Materials and Methods." Upper panels show representative autoradiographs from a single pair of rats. Lower panels demonstrate relative levels of 5-LO (soluble plus particulate fractions) (A) and FLAP (particulate fraction only) (B) in cells from both groups of animals as anlayzed by video densitometry. Levels in cells from $D$ - rats are expressed as a percentage of the paired $D+$ value and represent the mean \pm S.E.M. from 4 pairs of rats; ${ }^{*} p<0.05$. 


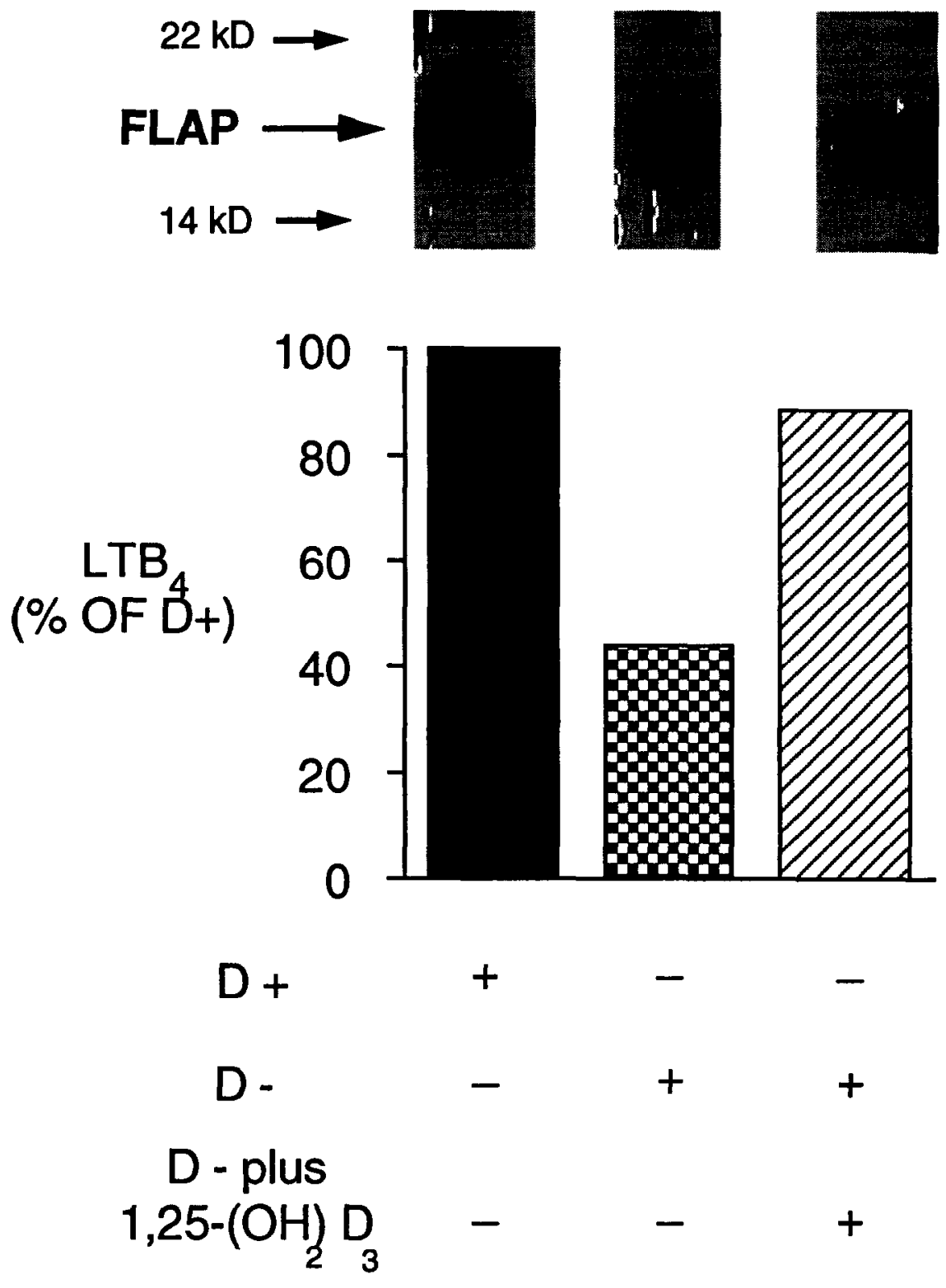

FIGURE 4. Effect of exogenous vitamin $D_{3}$ on FLAP expression and $\mathrm{LTB}_{4}$ synthesis in $A M$ from $D$ - rats. AM from $D+$ and $D$ - rats were adhered in $M 199$ for $1 \mathrm{~h}$, washed and then cultured overnight in $\mathrm{M} 199$ containing $10 \% \mathrm{FCS}$ with or without $1,25-(\mathrm{OH})_{2} \mathrm{D}_{3}(50 \mathrm{nM})$. (A) Autoradiograph depicting immunoblot analysis of FLAP. (B) A23187-induced ( $1 \mu \mathrm{M}$ for $30 \mathrm{~min}$ ) $\mathrm{LTB}_{4}$ synthetic capacity under the same conditions. In this experiment $A M$ from $D+$ rats $(3.9 \mathrm{ng} / \mathrm{ml})$ synthesized greater amounts of $\mathrm{LTB}_{4}$ than $\mathrm{AM}$ from $\mathrm{D}$ - rats $(1.7 \mathrm{ng} / \mathrm{ml})$, and this was almost completely restored $(3.5 \mathrm{ng} / \mathrm{ml})$ by overnight incubation with $1,25-(\mathrm{OH})_{2} \mathrm{D}_{3}$. 
Eicosanoid metabolism in vitamin $D_{3}$-deficient rats: Coffey et al.

COX Protein Expression in Macrophages and Type II AEC is Similar in $D+$ and $D-$ Rats

As indicated above, there was no significant difference in COX metabolism of AA in AM or PM from D - as compared to D + rats. To extend this finding, expression of COX proteins was determined in AM and PM from $\mathrm{D}+$ and $\mathrm{D}-$ rats. COX-2 was not detected in fresh $\mathrm{AM}$ or PM, which is consistent with its inducible role, ${ }^{11}$ but COX-1 was expressed in resting cells. Confirming the metabolic data, there was no reduction in COX-1 protein expression in either macrophage cell type obtained from $\mathrm{D}-$ rats $(\mathrm{AM}, 114.7 \pm 27.6 \%$ of $\mathrm{D}+; \mathrm{PM}, 92.8 \pm 18.5 \%$ of $\mathrm{D}+, \mathrm{n}=5)$. Figure 5A demonstrates a representative immunoblot analysis of COX-1 and COX-2 proteins in AM from D + and D - rats. Type II AEC line the alveolar surface, and have a high capacity for prostaglandin synthesis. ${ }^{19}$ Therefore, expression of COX proteins was examined in type II AEC isolated from $\mathrm{D}+$ and $\mathrm{D}-$ rats and harvested after $48 \mathrm{~h}$ in culture. These cells expressed both COX-1 and COX-2 proteins. There was no reduction in COX -1 or -2 expression in cells from $\mathrm{D}-$ animals $(126 \%$ and $118 \%$ of $\mathrm{D}+$, respectively, $\mathbf{n}=2$ ) (Figure $5 \mathrm{~B}$ ). 5-LO and FLAP expression were not detected (data not shown).

\section{Discussion}

We have previously demonstrated that PBM exhibit reduced FLAP expression compared to differentiated macrophages, ${ }^{7}$ and that $1,25-(\mathrm{OH})_{2} \mathrm{D}_{3}$ differentiated PBM exhibit a parallel increase in 5-LO metabolism of AA and FLAP expression. ${ }^{5}$ An increase in LT synthetic capacity in HL-60 cells incubated with $1,25-(\mathrm{OH})_{2} \mathrm{D}_{3}$ has also been reported. ${ }^{4}$ Consequently, the present study was performed to evaluate the physiological role of 1,25 $(\mathrm{OH})_{2} \mathrm{D}_{3}$ in regulating eicosanoid metabolism in mononuclear phagocytes. For comparison, type II AEC were studied. We examined both 5-LO and COX pathways in addition to the expression of 5-LO, FLAP, COX-1, and COX-2 proteins. Several important findings emerged from this study. 1) AM from D - rats demonstrated parallel reduction in 5-LO metabolism of AA and FLAP (but not of 5-LO) expression compared to AM from D+ rats. 2) 5-LO metabolism of AA was also reduced in PM from $D$ - rats, albeit without any significant change in FLAP expression. 3) The physiological role of vitamin $D_{3}$ appears to be specific for the 5-LO pathway, since its deficiency did not affect overall AA release in macrophages, the COX metabolic pathway or COX protein expression in either macrophages or type II AEC, or the 12-LO pathway in macrophages. 4) $1,25-(\mathrm{OH})_{2} \mathrm{D}_{3}$ concentrations in BAL and peritoneal lavage fluids exceeded that in serum, which may help explain the relatively greater FLAP expression in mature $A M$ and PM than in precursor PBM.

A unique feature of this study was our ability to address a possible in 


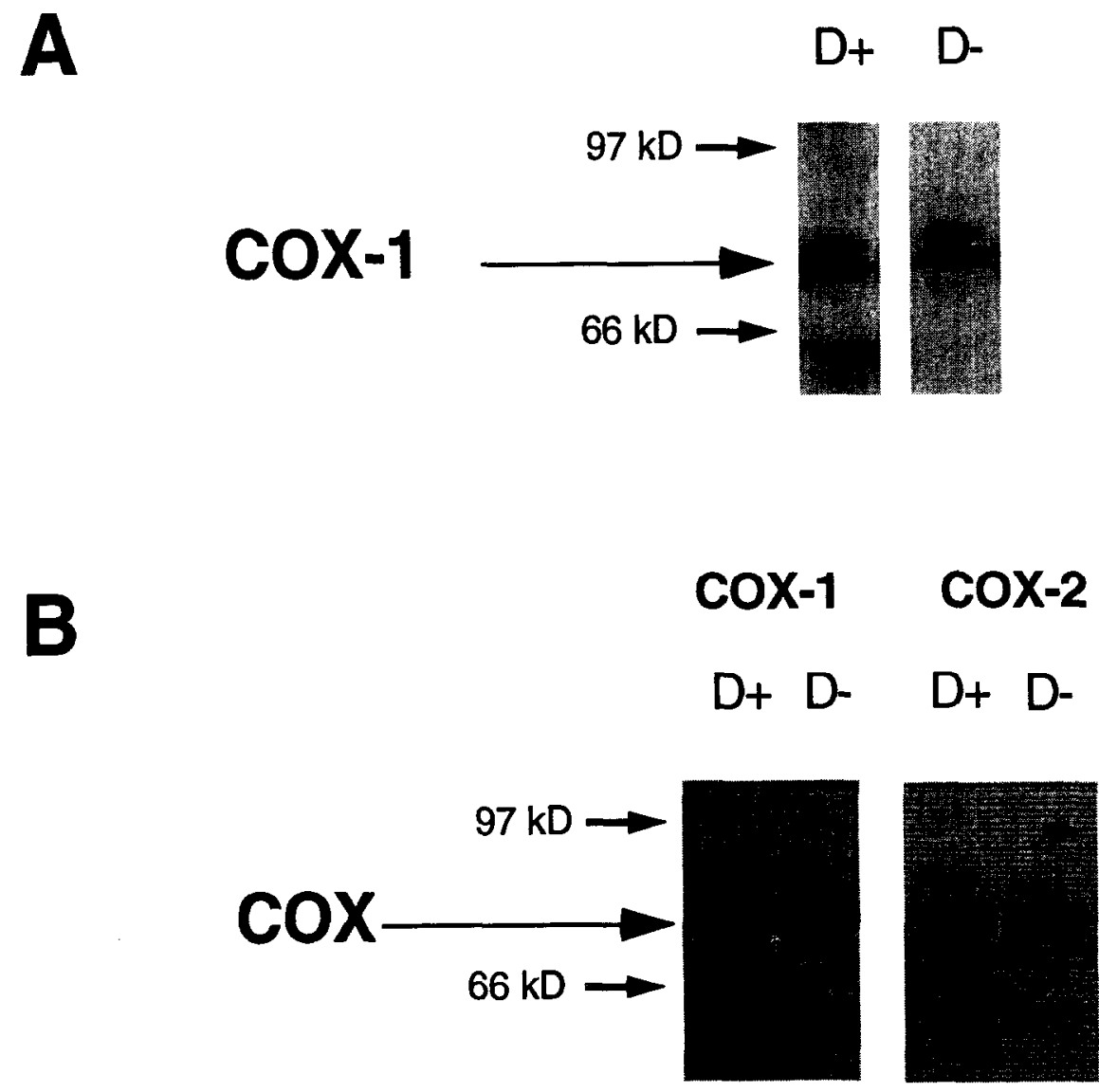

Figure 5. COX protein expression in $A M$ and type II AEC from $D+$ and $D-$ rats. (A) Particulate proteins $(7 \mu \mathrm{g})$ obtained from $A M$ from $D+$ and $D$ - rats were subjected to immunoblot analysis for COX-1, as described in the "Materials and Methods." (B) Particulate fractions $(20 \mu \mathrm{g})$ obtained from type II $A E C$ from $D+$ and $D$ - rats were subjected to immunoblot analysis for both COX-1 and COX-2, as described in the "Materials and Methods."

vivo role for $1,25-(\mathrm{OH})_{2} \mathrm{D}_{3}$ in regulating eicosanoid metabolism in macrophages by making use of an established rat model of vitamin $D_{3}$ deficiency. Determination of $1,25-(\mathrm{OH})_{2} \mathrm{D}_{3}$ levels in the serum verified the deficiency state of the experimental model. Interestingly, $1,25-(\mathrm{OH})_{2} \mathrm{D}_{3}$ levels in normal rats were 2.6-fold higher in BAL fluid and 1.6-fold higher in peritoneal lavage fluid than in serum. Greater $1,25-(\mathrm{OH})_{2} \mathrm{D}_{3}$ levels in these compartments than in serum might account for the greatly increased FLAP expression in AM and PM compared to PBM..$^{5}$ The mechanism underlying the greater $1,25-(\mathrm{OH})_{2} \mathrm{D}_{3}$ levels in $\mathrm{BAL}$ and peritoneal lavage 
fluid than in serum is unknown. Notably, resident AM from D- animals demonstrated a selective decrease in LT synthetic capacity which was associated with a significant decrease in FLAP expression, as compared to cells from matched $\mathrm{D}+$ rats. The magnitude of reduction in 5-LO metabolism of AA and in FLAP expression were quantitatively similar (i.e., $-50 \%$ of $\mathrm{D}+$ levels). That these defects were indeed a consequence of $1,25-(\mathrm{OH})_{2} \mathrm{D}_{3}$ deficiency was confirmed by showing that they were largely corrected by the addition of exogenous $1,25-(\mathrm{OH})_{2} \mathrm{D}_{3}$.

As compared to cells from normal rats, $\mathrm{PM}$ from $\mathrm{D}$ - rats exhibited a reduction in 5-LO metabolism of AA which was of similar magnitude to that observed in AM. However, this was not associated with a significant reduction in FLAP expression. These data in PM do not conform neatly to the hypothesis that FLAP expression is a function of $1,25-(\mathrm{OH})_{2} \mathrm{D}_{3}$ levels. An alternative explanation for this finding in PM includes the possible effect of vitamin $\mathrm{D}_{3}$ deficiency on other factors, apart from FLAP or 5-LO expression, which might regulate the 5-LO pathway. $1,25-(\mathrm{OH})_{2} \mathrm{D}_{3}$ is known to augment intracellular $\mathrm{Ca}^{2+}$ levels $^{23}$ and the transcription ${ }^{24}$ as well as activation of protein kinase C. ${ }^{29,31}$ Reduction in any of these effects might be expected to decrease the level of 5-LO metabolism of AA within the cell since LT synthetic capacity is dependent on intracellular $\mathrm{Ca}^{2+}$ concentrations ${ }^{28}$ and levels of active protein kinase $\mathrm{C}^{25}$

The effect of $1,25-(\mathrm{OH})_{2} \mathrm{D}_{3}$ appears to be specific for the 5-LO pathway, as vitamin $\mathrm{D}_{3}$ deficiency did not affect the total quantity of AA release or the metabolism of AA via the 12-LO or COX pathways in macrophages. The lack of effect on the COX pathway was confirmed by immunoblot analysis for COX-1, the constitutively expressed COX isoform, in AM and PM. COX-2 was not detected in fresh AM or PM. In type II AEC, which express COX-1 and COX-2, neither COX isoform was reduced in $\mathrm{D}$ - as compared to $\mathrm{D}+$ animals. This is in keeping with our previous data with $1,25-(\mathrm{OH})_{2} \mathrm{D}_{3}$-differentiated PBM, in which there was no significant effect on PG synthesis. ${ }^{5}$ By contrast, it has been previously reported that 1,25- $(\mathrm{OH})_{2} \mathrm{D}_{3}$ increased COX metabolism of AA in HL-60 cells. ${ }^{14}$ These results, which differed from those presented here, might be explained by differences in the cell type studied (malignant HL-60 cell line) or in culture conditions (lower $1,25-(\mathrm{OH})_{2} \mathrm{D}_{3}$ concentration, and serum-free Isocove's modified Dulbecco's medium).

In summary, our data strongly indicate that $1,25-(\mathrm{OH})_{2} \mathrm{D}_{3}$ is not merely capable of upregulating 5-LO metabolism of AA by increasing FLAP expression, as previously reported, ${ }^{5}$ but that $1,25-\left(\left.\mathrm{OH}\right|_{2} \mathrm{D}_{3}\right.$ plays a physiological role in maintaining FLAP expression and the 5-LO pathway in mature $\mathrm{AM}$ in vivo. Considering the role of 5-LO products, especially $\mathrm{LTB}_{4}$, as chemotactic factors important in normal host defense, ${ }^{20}$ this finding provides a possible explanation for the increased susceptibility to infection which has been recognized in association with $1,25-(\mathrm{OH})_{2} \mathrm{D}_{3}$ deficiency. ${ }^{2,12}$ 
Eicosanoid metabolism in vitamin $D_{3}$-deficient rats: Coffey et al.

\section{References}

1. Balter, M., G. Toews, and M. Peters-Golden. Different patterns of arachidonate metabolism in autologous human blood monocytes and alveolar macrophages. J Immunol 142: 602. 1989.

2. Bar-Shavit, Z., D. Noff, S. Edelstein, M. Meyer, S. Shibolet, and R. Goldman. 1,25-dihydroxyvitamin D3 and the regulation of macrophage function. Calcif Tissue Int 33: 673. 1981.

3. Barber, B., T. Schultz, and D. Randlett. Comparative analysis of protein content in rat mesenteric tissue, peritoneal fluid, and plasma. Am I Physiol: Gastrointest. Liver Physiol 258: G714. 1990.

4. Bennett, C., M. Chiang, B. Monia, and S. Crooke. Regulation of 5-lipoxygenase and 5-lipoxygenase-activating protein expression in $\mathrm{HL}-60$ cells. Biochem J 289: 33. 1993.

5. Coffey, M., M. Gyetko, and M. Peters-Golden. 1,25-Dihydroxyvitamin D3 upregulates 5-lipoxygenase metabolism and 5-lipoxygenase activating protein in peripheral blood monocytes as they differentiate into mature macrophages. J Lipid Med 6: 43. 1993.

6. Coffey, M., M. Peters-Golden, J. Fantone, and P. Sporn. Membrane association of active 5-lipoxygenase in resting cells: evidence for novel regulation of the enzyme in the rat alveolar macrophage. J Biol Chem 267: 570. 1992.

7. Coffey, M., S. Wilcoxen, and M. Peters-Golden. Increases in 5-lipoxygenase activating protein expression account for enhanced capacity for 5-lipoxygenase metabolism which accompanies differentiation of peripheral blood monocytes into alveolar macrophages. Am J Respir Cell Mol Biol 11: 153. 1994.

8. Dixon, R.A.F., R.E. Diehl, E. Opas, E. Rands, P.J. Vickers, J.F. Evans, J.W. Gillard, and D.K. Miller. Requirement of a 5-lipoxygenase-activating protein for leukotriene synthesis. Nature 343: 282. 1990.

9. Dobbs, L., R. Gonzalez, and M. Williams. An improved method for isolating type II cells in high yield and purity. Am Rev Respir Dis 134: 141. 1986.

10. Ford-Hutchinson, A. Leukotrienes: their formation and role as inflammatory mediators. Fed Proc 44: 25. 1985.

11. Fu, J.-Y., J.L. Masferrer, K. Seibert, A. Raz, and P. Needleman. The induction and suppression of prostaglandin $\mathrm{H}_{2}$ synthetase (cyclooxygenase) in human monocytes. J Biol Chem 265: 16737. 1990.

12. Gavison, R., and Z. Bar-Shavit. Impaircd macrophage activation in vitamin D3 deficiency: differential in vitro effects of 1,25-dihydroxyvitamin D3 on mouse peritoneal macrophage functions. J Immunology 143: 3686. 1989.

13. Hollis, B. Assay of circulating 1,25-dihydroxyvitamin D involving a novel single cartridge extraction and purification procedure. Clin Chem 32: 2060. 1986.

14. Honda, A., I. Morita, S. Murota, and Y. Mori. Appearance of the arachidonic acid metabolic pathway in human promyelocytic leukemia (HL-60) cells during monocytic differentiation: enhancement of thromboxane synthesis by 1,25-dihydroxyvitamin D3. Biochim Biophys Acta 877: 423. 1986.

15. Kargman, S, and C.A. Rouzer. Studies on the regulation, biosynthesis, and activation of 5-lipoxygenase in differentiated HL60 cells. J Biol Chem 264: 13313. 1989. 


\section{Eicosanoid metabolism in vitamin $D_{3}$-deficient rats: Coffey et al.}

16. Kreutz, M., and R. Andreesen. Induction of human monocyte to macrophage maturation in vitro by 1,25-dihydroxyvitamin D3. Blood 76:2457. 1990.

17. Laemmli, U. Cleavage of structural proteins during the assembly of the head of bacteriophage T4. Nature 227: 680. 1970.

18. Lewis, R., K. Austen, and R. Soberman. Leukotrienes and other products of the 5-lipoxygenase pathway: biochemistry and relation to pathobiology in human disease. N Engl J Med 323: 645. 1990.

19. Lipchik, R.J., J.B. Chauncey, R. Paine, R.H. Simon, and M. Peters-Golden. Arachidonate metabolism increases as rat alveolar type II cells differentiate in vitro. Am J Physiol (Lung Cell Mol Physiol. 3) 259: L73. 1990.

20. Martin, T., G. Raugi, T. Merritt, and W. Henderson Jr. Relative contribution of leukotriene B4 to the neutrophil chemotactic activity produced by the resident human alveolar macrophage. J Clin Invest 80: 1114. 1987.

21. McCarthy, D., J. San Miguel, H. Freake, P. Green, H. Zola, D. Catovsky, and J. Goldman. 1,25-dihydroxyvitamin D3 inhibits proliferation of human promyelocytic leukemia (HL60) cells and induces monocytic-macrophage differentiation in HL60 and normal human bone marrow cells. Leukemia Res 7: 51. 1983.

22. Miller, D.K., J.W. Gillard, P.J. Vickers, S. Sadowski, C. Leveille, J.A. Mancini, P. Charleson, R.A.F. Dixon, A.W. Ford-Hutchinson, R. Fortin, J.Y. Gauthier, J. Rodkey, R. Rosen, C. Rouzer, I.S. Sigal, C.D. Strader, and J.F. Evans. Identification and isolation of a membrane protein necessary for leukotriene production. Nature 343: 278. 1990.

23. Miyaura, C., E. Abe, and T. Suda. Extracellular calcium is involved in the mechanism of differentiation of mouse myeloid leukemia cells (M1) induced by 1,25-dihydroxyvitamin D3. Endocrinology 115: 1891. 1984.

24. Obeid, L., T. Okazaki, L. Karolak, and Y. Hannun. Transcriptional regulation of protcin kinase C by 1,25-dihydroxyvitamin D3 in HL-60 cells. J Biol Chem 265: 2370. 1990.

25. Peters-Golden, M., R.W. McNish, J.K. Brieland, and J.C. Fantone. Diminished protein kinase $\mathrm{C}$-activated arachidonate metabolism accompanies rat macrophage differentiation in the lung. J Immunol 144: 4320. 1990.

26. Peters-Golden, M., R.W. McNish, R. Hyzy, C. Shelly, and G.B. Toews. Alterations in the pattern of arachidonate metabolism accompany rat macrophage differentiation in the lung. J Immunol 144: 263. 1990.

27. Rouzer, C.A., and S. Kargman. Translocation of 5-lipoxygenase to the membrane in human leukocytes challenged with ionophore A23187. J Biol Chem 263: 10980. 1988.

28. Rouzer, C.A., and B. Samuelsson. On the nature of the 5-lipoxygenase reaction in human leukocytes: Enzyme purification and requirement for multiple stimulatory factors. Proc Natl Acad Sci 82: 6040. 1985.

29. van Leeuwen, J., J. Birkenhager, G. van den Bemd, C. Buurman, A. Staal, M. Bos, and $\mathrm{H}$. Pols. Evidence for the functional involvement of protein kinase $\mathrm{C}$ in the action of 1,25-dihydroxyvitamin D3 in hone. J Biol Chem 267: 12562. 1992.

30. von Wichert, P., K. Joseph, B. Muller, and W. Franck. Bronchoalveolar lavage: quantitation of intraalveolar fluid. Am Rev Respir Dis 147: 148.1993.

31. Wali, R., C. Baum, M. Sitrin, and T. Brasitus. 1,25(OH)2 vitamin D3 stimu- 
Eicosanoid metabolism in vitamin $D_{3}$-deficient rats: Coffey et al.

lates membrane phosphoinositide turnover, activates protein kinase $\mathrm{C}$, and increases cytosolic calcium in rat colonic epithelium. J Clin Invest 85: 1296. 1990.

32. Weishaar, R., and R. Simpson. Vitamin D3 and cardiovascular function in rats. J Clin Invest 79: 1706. 1987.

Editor: M. Goldyne

Received: $5-9-94$

Accepted: 9-25-94

\section{Acknowledgments}

\section{Abbreviations}

AA, arachidonic acid; AEC, alveolar epithelial cell; AM, alveolar macrophage; BAL, bronchoalveolar lavage; BSA, bovine serum albumin; COX, cyclooxygenase; DMEM, Dulbecco's modified Eagles' medium; DMSO, dimethyl sulfoxide; EIA, enzyme immunoassay; FLAP, 5-lipoxygenase activating protein; HEPES, 4-(2-hydroxyethyl)-1-piperazineethanesulfonic acid; 5-HETE, 5-(S)-hydroxy-6,8,11,14-eicosatetraenoic acid; 12-HETE, 12(S)-hydroxy-6,8,11,14-eicosatetraenoic acid; HHT, 12-hydroxyheptadecatrienoic acid; HL-60 cells, human lymphoma 60 cells; HPLC, high performance liquid chromatography; 5-LO, 5-lipoxygenase; 12-LO, 12-lipoxygenase; $\mathrm{LTB}_{4}$, leukotriene $\mathrm{B}_{4}((5 \mathrm{~S}, 12 \mathrm{R})$-dihydroxy-6, 14-cis-8,14trans-eicosatetraenoic acid); PBM, peripheral blood monocyte; PBS, phosphate buffered saline; $\mathrm{PGE}_{2}$, prostaglandin $\mathrm{E}_{2} \mathrm{PM}$, peritoneal macrophage; SDS, sodium dodecyl sulfate; $\mathrm{TxB}_{2}$, thromboxane $\mathrm{B}_{2} ; \mathrm{TBS}$, Tris buffered saline; $1,25-\left(\left.\mathrm{OH}\right|_{2} \mathrm{D}_{3}\right.$, 1,25-dihydroxy vitamin $\mathrm{D}_{3}$; normal/control rats $(\mathrm{D}+)_{\text {; vitamin }} \mathrm{D}_{3}$-deficient $(\mathrm{D}-)$.

This work was supported by grants from the National Institute of Health (Grants HL-47391 and Specialized Center of Research HL-46487), and the Research Service of the Department of Veterans Affairs. 